\title{
Engineering Candidates' Metaphorical Perceptions of About Energy
}

\author{
Nilüfer Cerit Berber
}

Correspondence: Nilüfer Cerit Berber, Ahmet Keleşoğlu Education Faculty, Department of Physics Education, Necmettin Erbakan University, Konya, Turkey.

Received: September 10, 2018

doi:10.11114/jets.v6i12.3612

\author{
Accepted: October 10, 2018 \\ Online Published: October 24, 2018 \\ URL: https://doi.org/10.11114/jets.v6i12.3612
}

\begin{abstract}
It is generally difficult to define abstract concepts for students. However, perceptions related to abstract concepts or facts can be revealed using metaphors because people frequently express their emotions, ideas and perceptions by means of metaphors. Through metaphors, students can express what they want to say more effectively with fewer words. Metaphorical perceptions are verbal expressions of individuals related to their perceptions about the external world, and these may help them to reveal the current situation related to the concept on their minds. Energy is a complex concept since it is abstract as well as it concerns all scientific fields. The purpose of this study is to determine metaphorical perceptions of the engineering candidates about energy. The research was conducted using the phenomenological research method which is a qualitative research method. The research population consisted of 148 grade 3 students who were studying at Necmettin Erbakan University Faculty of Engineering and Architecture during the spring semester of Academic Year in 2016-2017. Considering the results of the research, the metaphors of the engineering candidates about energy were classified in 7 categories. These categories are; energy as the reason of existence, energy as an issue of physics, energy as the base of technology, energy as the base of development, energy as a non consumable substance, energy as a consumable substance and energy as a transformable substance.
\end{abstract}

Keywords: metaphorical perception, energy, engineering candidates

\section{Introduction}

Science is a field which includes instruments and methods of benefiting from nature and analyzes nature in a way that people can understand. The necessity and significance of science literacy is significant for a strong future in this regard (Eş \& Sarıkaya, 2010). It is seen that a considerable number of researches conducted in the field of science education are based on misconceptions. Misconceptions are concepts causing students have difficulty in structuring knowledge, and misconceptions generally occur about abstract concepts because students have trouble describing abstract concepts (Güneş \& Karaşah, 2016). Researchers conducted on science education show that especially abstract concepts forming most of the science concepts are not understood directly, other domains and concrete experiences are effective on grasping abstract concepts (Niebert, Marsch \& Treagust 2012). On the other hand, metaphors can be used in comprehending abstract concepts because metaphors help students' associate things that they do not know with things they know (Marzano, Gaddy \& Dean 2000). Metaphors are words or phrases used by individuals while expressing concepts or facts (Lakoff \& Johnson, 2005). Metaphorical perceptions are the verbal expressions of individuals' perceptions about the external world and these might help them reveal the situation related to the abstract concept on their minds (Tamimi, 2005). In metaphorical perceptions, a connection is established between two different concepts and a specific mental schema is reflected on another mental schema (Saban, 2009). At this point it is observed that the most significant factor which is effective on learning is preconceptions of an individual (Niebert, Marsch \& Treagust, 2012). The power of metaphors in explaining abstract concepts has caused a rise in the number of educational researches which aim revealing metaphorical perceptions about different concepts.

Perhaps "energy" is one of the leading concepts about which students have perceptions far from being scientific because of being both abstract and the common issue of all science disciplines. Although energy is abstract, it is a concept we face in daily life and we need and contain within ourselves. Energy is also one of the most basic inputs of social and economical development and it is important for all world countries. Knowing metaphorical perceptions of students about energy might provide significant answers about how to teach energy concept. By determining metaphorical perceptions of engineering students through energy concept, which is the issue of all science disciplines and a common issue of all engineering branches, results which may shape energy education can be provided. Therefore, what is 
purposed in this research is to determine metaphoric perceptions of engineering candidates about energy. In the direction of this purpose, sub-problems of the research are;

1- What metaphors do engineering candidates create about energy concept?

2- In which conceptual categories can these metaphors be gathered in terms of their common characteristics?

3- Do the determined conceptual categories differ from each other according to the department in which the engineering candidates study?

4- Do the determined categories differ from each other by gender?

\section{Method}

\subsection{Research Model}

The research was conducted in accordance with phenomenological research model. In phenomenological research model, the focus is on facts which we are aware of but we do not have thorough and detailed comprehension about them (Yıldırım \& Şimşek, 2011). Besides a phenomenological research is gathering experiences of a few people related to a phenomenon or a concept around a common sense (Creswell, 2013).

\subsection{Research Population}

The sampling of the research consisted of 148 grade 3 students who were studying at Necmettin Erbakan University Faculty of Engineering and Architecture during the spring semester of Academic Year in 2016-2017. In Table 1, the distribution of the engineering candidates included in the research sampling by department and gender is seen.

Table 1: Distribution of the engineering candidates included in the research sampling by department and gender

\begin{tabular}{llll}
\hline Department & Male & Female & Total \\
\hline Civil Engineering & 15 & 4 & 19 \\
Electrical Electronic Engineering & 15 & 5 & 20 \\
Energy Systems Engineering & 14 & 3 & 17 \\
Environmental Engineering & 9 & 17 & 26 \\
Food Engineering & 2 & 29 & 31 \\
Industrial Engineering & 5 & 9 & 14 \\
Mechanical Engineering & 14 & 7 & 21 \\
Total & $\mathbf{7 4 ( 5 0 \% )}$ & $\mathbf{7 4}(\mathbf{5 0 \%})$ & $\mathbf{1 4 8}$ \\
\hline
\end{tabular}

\subsection{Data Collection}

In order to collect data, a sheet of paper including the sentence "Energy is like ............ because ......................." was delivered to the engineering candidates to complete, and they were given 20 minutes to complete.

\subsection{Data Analysis}

Along with the description of subjects, give the mended size of the sample and number of individuals meant to be in each condition if separate conditions were used. State whether the achieved sample differed in known ways from the target population. Conclusions and interpretations should not go beyond what the sample would warrant.

The data collected in the research were analyzed using "content analysis technique". Content analysis is defining what people say or write by coding. Here the purpose is to obtain concepts and relationships which might explain the meaning of collected data (Yıldırım \& Şimşek, 2011). The content analysis technique was done in phases;

1- Eliminating and Selecting: By taking engineering candidates' focusing on an apparent metaphorical image and proving a logical explanation related to this metaphorical image into consideration, the papers which would be included in the next phase were selected. The papers in which metaphors were not understood clearly, metaphors and explanations did not correspond with each other or any explanations were not made were eliminated. As a result, 15 papers were eliminated and the metaphors belonging to 148 engineering candidates were included in the research.

2- Coding: Metaphors were determined by separately examining 148 papers which included metaphorical expressions belonging to the engineering candidates and each of them was coded by assigning a numerical value beginning with number 1 . Thus, we obtained 92 valid metaphors.

3- Categorization: 92 valid metaphors were classified by considering their common characteristics related to energy 
concept and which characteristic was emphasized by the candidates. In order to provide the reliability of the research, expert opinions were taken. Opinions of an expert in physics education, an expert in chemistry education, an expert in biology education and an expert in Turkish education were taken for this purpose. All of the experts whose opinions were taken reported that the categories which were determined according to the metaphorical expressions were appropriate and there was an agreement among experts. As a result, the metaphors were collected in 7 different conceptual categories.

\section{Results}

\subsection{Findings on Outstanding Metaphors Related to Energy}

As a result of data analysis, it was detected that 148 engineering candidates constituted 92 types of metaphors which were gathered in 7 conceptual categories related to energy. The average number of engineering candidates per metaphor is approximately 2 . Twenty three of 92 created metaphors were above average, that is to say they were expressed twice and more, whereas 69 metaphors were below average, that's to say, they were expressed once. 23 metaphors outstanding in the research are given in Table 2.

Table 1. Frequency distribution of outstanding metaphors according to metaphor categories

\begin{tabular}{|c|c|c|c|c|c|c|c|c|}
\hline Metaphors & $\begin{array}{l}\text { The reason } \\
\text { of existence }\end{array}$ & $\begin{array}{r}\text { An issue of } \\
\text { physics }\end{array}$ & $\begin{array}{l}\text { The base of } \\
\text { development }\end{array}$ & $\begin{array}{r}\text { The } \\
\text { consumable } \\
\text { substance }\end{array}$ & $\begin{array}{r}\text { The } \\
\text { transformable } \\
\text { substance }\end{array}$ & $\begin{array}{r}\text { The base } \\
\text { of } \\
\text { technology }\end{array}$ & $\begin{array}{r}\text { The non } \\
\text { consumable } \\
\text { substance }\end{array}$ & Total \\
\hline Life & 11 & & 1 & 2 & 2 & & & 16 \\
\hline Power & 1 & 5 & 3 & & & 1 & & 10 \\
\hline Living & 5 & & 1 & & & & & 6 \\
\hline Work & & 6 & & & & & & 6 \\
\hline The Sun & 4 & & & & & 1 & 1 & 6 \\
\hline Water & 6 & & & & & & & 6 \\
\hline Human & 4 & & & 1 & & & & 5 \\
\hline Movement & & 3 & & & & & & 3 \\
\hline Electricity & & 2 & & & & 1 & & 3 \\
\hline Light & 2 & & & & & 1 & & 3 \\
\hline ATP & 3 & & & & & & & 3 \\
\hline Food & 3 & & & & & & & 3 \\
\hline Production & & & 3 & & & & & 3 \\
\hline Money & & & 2 & 1 & & & & 3 \\
\hline $\begin{array}{l}\text { Renewable } \\
\text { resource }\end{array}$ & & & & & 3 & & & 3 \\
\hline Physics & & 2 & & & & & & 2 \\
\hline Oxygen & 2 & & & & & & & 2 \\
\hline Need & 2 & & & & & & & 2 \\
\hline Health & 1 & & & 1 & & & & 2 \\
\hline Happiness & 2 & & & & & & & 2 \\
\hline Air & 2 & & & & & & & 2 \\
\hline Gasoline & & & & 2 & & & & 2 \\
\hline
\end{tabular}

3.2 Findings on Conceptual Categories Related to Energy

The metaphors created by the engineering candidates and their frequencies and the conceptual categories in which they were included and their frequencies are given in Table 3. 
Table 3. The metaphors related to energy concept and their categories

\begin{tabular}{|c|c|c|c|}
\hline $\begin{array}{l}\text { Metaphor } \\
\text { Categories }\end{array}$ & Metaphors $(f)$ & $f$ & $\%$ \\
\hline $\begin{array}{l}\text { Energy as the } \\
\text { reason of existence }\end{array}$ & $\begin{array}{l}\text { Life (11), Water (6), Living (5), Human (4), The Sun (4), ATP (3), Food (3), Need } \\
\text { (2), Oxygen (2), Happiness (2), Light (2), Air (2), Life source (1), Life philosophy } \\
\text { (1), Power (1), Meal (1), Breath (1), Source of vitality (1), Spark of life (1), Living } \\
\text { being (1), Big Bang (1), Health (1), Sparkle (1), Bread (1), Aliveness (1), Soul (1), } \\
\text { Heart (1). }\end{array}$ & 61 & 41 \\
\hline $\begin{array}{l}\text { Energy as an issue } \\
\text { of physics }\end{array}$ & $\begin{array}{l}\text { Work (6), Power (5), Movement (3), Physics (2), Electricity (2), Speed (1), Force (1), } \\
\text { Temperature (1), Heat (1), Length (1). }\end{array}$ & 23 & 16 \\
\hline $\begin{array}{l}\text { Energy as the base } \\
\text { of development }\end{array}$ & $\begin{array}{l}\text { Power (3), Production (3), Money (2), Nuclear Energy (1), Development (1), Life } \\
\text { (1), War (1), Effort (1), Labor (1), Project (1), Ant (1), Living (1), Elon Musk (1). }\end{array}$ & 18 & 12 \\
\hline $\begin{array}{l}\text { Energy as a } \\
\text { consumable } \\
\text { substance }\end{array}$ & $\begin{array}{l}\text { Life (2), Gasoline (2), Car (1), Nature (1), Limited Resource (1), Charged battery (1), } \\
\text { Fuel (1), Time (1), Natural Resource (1), Money (1), Human (1), Health (1), Organ } \\
\text { (1). }\end{array}$ & 15 & 10 \\
\hline $\begin{array}{l}\text { Energy as a } \\
\text { transformable } \\
\text { substance }\end{array}$ & $\begin{array}{l}\text { Life (2), Renewable resource (2), Transformable Resources (1), God (1), Eternity (1), } \\
\text { Space (1), Substance (1), Cycle (1), Form (1), Mode (1), Breath (1), Play dough (1). }\end{array}$ & 14 & 10 \\
\hline $\begin{array}{l}\text { Energy as the base } \\
\text { of technology }\end{array}$ & $\begin{array}{l}\text { Machine (1), Easiness (1), Electricity (1), Light (1), Power (1), Wind rose (1), The } \\
\text { Sun (1), System (1), Technology (1). }\end{array}$ & 9 & 6 \\
\hline $\begin{array}{l}\text { Energy as a non } \\
\text { consumable } \\
\text { substance }\end{array}$ & $\begin{array}{l}\text { The Sun(1), Endless resource(1), Fuel of nature (1), First steps (1), Ball-point pen } \\
\text { (1), Justice of the universe (1), The Universe (1), Hyperactive child (1). }\end{array}$ & 8 & 5 \\
\hline TOTAL & & 148 & 100 \\
\hline
\end{tabular}

Category 1: Energy as the reason of existence

This category which was represented by 61 engineering candidates and included 27 types of metaphors is on the first rank. Approximately $41 \%$ of engineering candidates created metaphors related to energy which go into this category. In this category, the vital importance of energy to living beings is emphasized and "Life" metaphor becomes prominent. Some of the metaphors included in this category are as follows:

"Energy is like life because everything in nature needs energy and energy is necessary for their continuity." (Female, Food Engineering)

"Energy is like water because the meaning of energy to the universe is the same as water's importance to human nature." (Female Food Engineering)

"Energy is like the Sun because the Sun provides the energy necessary for the life in the world." (Female, Environmental Engineering)

"Energy is like human beings because every metaphysical thing possessed by human beings such as spirit, emotions is actually energy." (Male, Civil Engineering)

"Energy is like air because air is necessary for many life functions such as breathing, photosynthesis." (Female, Food Engineering)

Category 2: Energy as an issue of physics

The category which was represented by 23 engineering candidates and included 10 types of metaphors ranked second. Around $16 \%$ of the engineering candidates created metaphors related to energy which are contained in this category. In this category, the relation between energy and physics course, the issues taught in physics course are emphasized. "Work" metaphor comes to the forefront. Some of the metaphors included in this category are as follows:

"Energy is like work because you need energy to do work." (Female, Environmental Engineering)

"Energy is like force because we need both energy and force to do work." (Male, Industrial Engineering)

"Energy is like movement because if there is energy, there is a movement" (Male, Civil Engineering)

"Energy is like power because if there is power, there is work, if there is work, there is energy" (Female, Food Engineering)

"Energy is like speed because kinesthetic energy depends on speed" (Male, Civil Engineering)

Category 3: Energy as the base of development

This category including 18 engineering candidates and 13 metaphors ranked third. Approximately $12 \%$ of the engineering candidates created energy-related metaphors which go into this category. Positive effects of energy on the development of a country are emphasized. "Power" and "Production" metaphors become prominent. Some of the metaphors included in this category are as follows: 
"Energy is like power because development of a country is determined according to its external dependence. Those countries which produce their own energy never become external dependent and they protect their power." (Male, Energy Systems Engineering)

"Energy is like strength because energy wars are fought for strength. Strength means power." (Female, Mechanical Engineering)

"Energy is like production because the secret of developed countries is being able to produce. Societies that produce live on welfare. Total independence is possible with energy."

(Male, Electrical- Electronic Engineering)

"Energy is like production because works in industry are done with energy. If there is no energy, there is no production." (Female, Mechanical Engineering)

"Energy is like Elon Musk because just as Elon Musk energizes people, energy achieves work by energizing." (Male, Industrial Engineering)

Category 4: Energy as a consumable substance

The category ranking fourth was represented by 15 engineering candidates and with 13 metaphors. Around $10 \%$ of the engineering candidates created energy-related metaphors which were included in this category. It is emphasized that energy may deplete and it is valuable. "Life" and "Gasoline" metaphors become prominent. Some of the metaphors included in this category are as follows:

"Energy is like life because it depletes over time." (Male, Civil Engineering)

"Energy is like gasoline because a car needs gasoline to move and energy is needed to do work" (Female, ElectricalElectronic Engineering)

"Energy is like human beings because they are sometimes there, but sometimes not" (Female, Electrical- Electronic Engineering)

"Energy is like money because when it is not used properly, you are in need of it." (Male, Mechanical Engineering)

"Energy is like time because it should not be wasted." (Male, Civil Engineering)

Category 5: Energy as a transformable substance

This category which included 14 engineering candidates and 12 metaphors ranked fifth. About $10 \%$ of the engineering candidates created energy-related metaphors which were included in this category. It is emphasized that energy never disappears, it just transforms into different forms. "Life" and "Renewable resource" metaphors come to the forefront. Some of the metaphorical expressions included in this category are as follows:

"Energy is like renewable resources because it is possible to obtain it from the Sun and wind again and again." (Female, Environmental Engineering)

"Energy is like life because it is continually in a cycle like eating, drinking, sleeping every day." (Male, Energy Systems Engineering)

"Energy is like play dough because you can shape it." (Male, Electrical- Electronic Engineering)

"Energy is like a breath because while you consume something, you produce another thing. There is such a cycle in energy." (Male, Electrical- Electronic Engineering)

Category 6: Energy as the base of technology

This category including 9 engineering candidates and 9 metaphors ranked sixth. $6 \%$ of the engineering candidates created energy-related metaphors which went into this category. It is emphasized that all technological developments are based upon energy control. There are no metaphors that come to the forefront. Some of the metaphors taking place in this category are as follows:

"Energy is like technology because it is necessary for comfort and easiness of life." (Male, Electrical-Electronic Engineering)

"Energy is like a project because it is similar to a project in which intended results are obtained with proper data at the right time." (Female, Mechanical Engineering)

"Energy is like a car because both of them require productive use, both of them serve the purpose, both of them have power and you can move forward using both of them." (Male, Energy Systems Engineering)

"Energy is like a system because it is multi-functional and it is present everywhere." (Female, Food Engineering) 
Category 7: Energy as a non consumable substance

The category ranking seventh and last included 8 engineering candidates and 8 metaphors. Approximately $5 \%$ of the engineering candidates created energy-related metaphors in this category. It is emphasized that energy never depletes. There are no metaphors becoming prominent. Some of the metaphors included in this category are as follows:

"Energy is like space because it is endless." (Male, Environmental Engineering)

"Energy is like God because it cannot be destroyed." (Male, Energy Systems Engineering)

"Energy is like the Sun because it rises again, even if it sets." (Female, Civil Engineering)

"Energy is like the universe because there is energy everywhere in the universe. Luckily there is." (Female, Mechanical Engineering)

\subsection{Findings Related to the Comparison of Metaphor Categories According to Engineering Departments}

The frequency and percentage values belonging to the distribution of conceptual categories of the engineering candidates according to the departments in which they were studying are given in Table 4 .

Table 4. Distribution of metaphor categories according to the departments

\begin{tabular}{|c|c|c|c|c|c|c|c|c|c|c|c|c|c|c|c|c|}
\hline \multirow[t]{2}{*}{$\begin{array}{l}\text { Metaphor } \\
\text { categories }\end{array}$} & \multirow{2}{*}{\multicolumn{2}{|c|}{$\begin{array}{rr}\begin{array}{r}\text { Civil } \\
\text { En. }\end{array} \\
f & \%\end{array}$}} & \multicolumn{2}{|c|}{$\begin{array}{l}\text { Electri.- } \\
\text { Electro. }\end{array}$} & \multicolumn{2}{|c|}{$\begin{array}{l}\text { Energy } \\
\text { Sys. En. }\end{array}$} & \multicolumn{2}{|c|}{$\begin{array}{r}\begin{array}{r}\text { Environ. } \\
\text { En. }\end{array} \\
\end{array}$} & \multicolumn{2}{|r|}{$\begin{array}{r}\text { Food } \\
\text { En. }\end{array}$} & \multicolumn{2}{|c|}{$\begin{array}{r}\begin{array}{r}\text { Industrial } \\
\text { En. }\end{array}\end{array}$} & \multicolumn{2}{|c|}{$\begin{array}{r}\begin{array}{r}\text { Mechan. } \\
\text { En. }\end{array} \\
\end{array}$} & \multicolumn{2}{|r|}{ Total } \\
\hline & & & $\bar{f}$ & $\%$ & $\bar{f}$ & $\%$ & $\bar{f}$ & $\%$ & $\bar{f}$ & $\%$ & $f$ & $\%$ & $\bar{f}$ & $\%$ & $\bar{f}$ & $\%$ \\
\hline $\begin{array}{l}\text { Energy as the } \\
\text { reason of existence }\end{array}$ & 8 & 42.1 & 3 & 15 & 7 & 41.2 & 5 & 19.2 & 20 & 64.5 & 6 & 42.8 & 13 & 61.9 & 61 & 40.7 \\
\hline $\begin{array}{l}\text { Energy as an issue } \\
\text { of physics }\end{array}$ & 6 & 31.6 & 3 & 15 & 1 & 5.9 & 5 & 19.2 & 5 & 16.1 & 3 & 21.4 & 0 & 0 & 23 & 15.3 \\
\hline $\begin{array}{l}\text { Energy as the base } \\
\text { of development }\end{array}$ & 1 & 5.3 & 4 & 20 & 6 & 35.3 & 1 & 3.8 & 1 & 3.2 & 1 & 7.1 & 4 & 19 & 18 & 12.7 \\
\hline $\begin{array}{l}\text { Energy as a } \\
\text { consumable } \\
\text { substance }\end{array}$ & 1 & 5.3 & 6 & 30 & 2 & 11.7 & 2 & 7.7 & 1 & 3.2 & 2 & 14.2 & 1 & 4.8 & 15 & 10 \\
\hline $\begin{array}{l}\text { Energy as a } \\
\text { transformable } \\
\text { substance }\end{array}$ & 0 & 0 & 3 & 15 & 1 & 5.9 & 8 & 30.8 & 2 & 6.5 & 0 & 0 & 0 & 0 & 14 & 10 \\
\hline $\begin{array}{l}\text { Energy as the base } \\
\text { of technology }\end{array}$ & 2 & 10.5 & 1 & 5 & 0 & 0 & 4 & 15.3 & 1 & 3.2 & 1 & 7.1 & 0 & 0 & 9 & 6 \\
\hline $\begin{array}{l}\text { Energy as a non } \\
\text { consumable } \\
\text { substance }\end{array}$ & 1 & 5.3 & 0 & 0 & 1 & 5.9 & 1 & 3.8 & 1 & 3.2 & 1 & 7.1 & 3 & 14.2 & 8 & 5.3 \\
\hline
\end{tabular}

According to Table 4, while food, mechanical, industrial, energy systems and civil engineering candidates respectively created energy-related metaphors which go into the "energy as the reason of existence" conceptual category; environmental engineering candidates created metaphors which go into the "energy as a transformable substance" category.

The departments which associated energy with existence are mostly food and mechanical engineering, the department which associated energy with physics course is civil engineering, the department of environmental engineering associated it with technology, the department which correlated it with development is energy systems engineering, the department which considered it as a non-consumable substance is mechanical engineering, the department which considered it as a consumable substance is electrical-electronic engineering and the department of environmental engineering considered it as a transformable substance.

\subsection{Findings Related to the Comparison of Metaphor Categories by Gender}

The frequency and percentage values belonging to the distribution of the determined conceptual categories of the engineering candidates by gender are given in Table 5 . 
Table 5. Distribution of metaphor categories by gender

\begin{tabular}{lrrrrrr}
\hline \multirow{2}{*}{ Metaphor categories } & \multicolumn{2}{c}{ Females } & \multicolumn{3}{c}{ Males } & \multicolumn{3}{r}{ Total } \\
& $\mathrm{f}$ & $\%$ & $\mathrm{f}$ & $\%$ & $\mathrm{f}$ & $\%$ \\
\hline Energy as the reason of existence & 36 & 48.6 & 25 & 33.7 & 61 & 40.7 \\
Energy as an issue of physics & 12 & 16.2 & 11 & 14.8 & 23 & 15.3 \\
Energy as the base of development & 6 & 8.1 & 12 & 16.2 & 18 & 12.7 \\
Energy as a consumable substance & 6 & 8.1 & 9 & 12.1 & 15 & 10 \\
Energy as a transformable substance & 4 & 5.4 & 10 & 13.5 & 14 & 10 \\
Energy as the base of technology & 5 & 6.8 & 4 & 5.4 & 9 & 6 \\
Energy as a non consumable substance & 5 & 6.8 & 3 & 4.0 & 8 & 5.3 \\
Total & 74 & 100 & 74 & 100 & 148 & 100 \\
\hline
\end{tabular}

Most of the female and male engineering candidates associated energy with existence. In addition, while female engineering candidates correlated energy with physics course, male engineering candidates associated energy with development and transformation, along with physics course.

\section{Discussion}

In this research, metaphorical perceptions of the engineering candidates about energy concept have been revealed. Findings show that perceptions of the engineering candidates about energy are shaped by their belief that energy is significant for life and development of a country, energy has a connection with physics course and technology, energy will deplete, energy will not deplete and energy transforms. One of the most remarkable findings is that the metaphors expressed by nearly all the engineering candidates are generally included in "Energy as the reason of existence" category. It is likely to say that a general (holistic) approach to energy concept is exhibited here. Basic function of energy is to provide the continuity of lives of living beings, regardless of energy type or structure.

Another remarkable finding obtained in the research is associating energy with physics course. It is possible to say that this is a result of education dependent on disciplines. Although energy concept is an interdisciplinary concept, it is interesting that it is associated with only physics course. This is a situation which has been revealed in other researchers conducted on energy perceptions. (Güneş \&Taştan Akdağ, 2016; Kılıç \& Cerit Berber, 2018; Töman \& Odabaşı Çimer, 2011; Töman \& Odabaşı Çimer, 2012; Ünal Çoban, Aktamış \& Ergin, 2007; Yürümezoğlu, Ayaz \& Çökelez, 2009). Besides researches conducted on the question "What is energy?" show that students generally define energy as "the ability to do work" or they write formulas. Furthermore, it has also been observed that although students can write this definition which is mostly made in physics courses, they cannot explain it (Chabalengula, Sanders \& Mumba, 2011; Güneş \& Taştan Akdağ, 2016). The reason is that it is not possible to define another concept before defining a concept and not understanding work concept causes not understanding energy concept as well (Diakidoy, Kendeou \& Ioannides, 2003; Domenechetal, 2007; Hırça, Çalık \& Akdeniz, 2008; Lancor, 2012; Taber, 1989). Consequently, it is possible to say that an interdisciplinary definition related to energy could not be made, there is only one definition which is in the physical context but it has deficiencies.

After the industrial revolution, economies in which machinery manufacturing and industry were dominant replaced economies which depended on labor force. Next, economic development and growth have become dependent on energy use and the rest of work has largely become experts' task, that is to say engineers' task (Beaudreau, 2005). Therefore, the purpose of engineering science is to create applications which focus on productive use and proper management of energy and which are mostly technological. In the direction of these ideas, it is possible to expect that the approach of engineering candidates to energy ought to be in the context of development and technology. However, the results of the research show that nearly $18 \%$ of energy-related metaphoric perceptions of the engineering candidates go into the categories of "Energy as the base of development" and "Energy as the base of technology". Accordingly, it is possible to say that the engineering candidates have deficiencies in terms of their awareness of the purpose of their occupation and the role of energy in this purpose.

The results of the research have revealed that the engineering candidates are undecided between "to deplete, not to deplete and to transform" which can be qualified as characteristics of energy. $10 \%$ of the candidates created metaphors defining energy as a consumable substance, $10 \%$ of them produced metaphors defining energy as a transformable substance and 5\% of them created metaphors defining energy as a non-consumable substance. It is likely to say that there is a confusion related to the characteristics of energy on their minds. Conservation of energy, degradation of energy, transformation of energy and transfer of energy are the basic characteristics of energy. Those candidates who 
create metaphors related to energy as "a non-consumable substance" emphasize conservation of energy primarily, and then they emphasize transformation of energy. Those who create metaphors related to energy as "transformable substance" put emphasis on energy transformation primarily, and then on energy conservation. Those who consider energy as "a consumable substance" emphasize degradation of energy. Those who express that energy is conserved and transformed will not be able to explain degradation of energy. Similarly, those who express that energy degrades cannot explain energy conservation and transformation. It is attention grabbing that the candidates never emphasize energy transfer. Actually what we see here is the negative effect of interdisciplinary-based teaching on energy because contrary to the importance attached to energy in physics courses, energy lose in systems is emphasized in biology courses (Campbell \& Reece, 2002; Lancor, 2012). Similarly, in chemistry courses, it is said that energy loss occurs in exothermic reactions. This situation can make difficult to comprehend other subjects related to energy. For example, "the principle of conservation of energy" which states that energy cannot be created out of nothing might block comprehending the concept "renewable energy". In this regard, energy as a subject must be taught as a whole in an interdisciplinary understanding. Many physicists advocated that learning energy conservation with energy transformation, transfer and degradation would provide a complete understanding about energy (Duit \& Haeussler, 1994; Hect, 2007; Lee \& Liu, 2010). In addition, using alternative learning approaches in teaching an abstract and interdisciplinary concept like energy is important in providing meaningful learning. Close and Scherr (2015) showed that an environment which was blended with student interactions such as body movements, gestures and speeches which are called energy theater was effective on comprehending energy transfer and transformation.

When distribution of metaphor categories is considered according to departments, it is seen that there are differences in terms of energy perceptions among departments. It is possible to think that differences among curricula followed in departments cause these differences. A high-level university education must rely on a well-planned curriculum. In their research conducted with energy engineering faculty members and students, Malkki and Paatero (2014) display that strategic curriculum planning is necessary for university education.

Energy is one of the most important inputs of sustainable economical and social development of societies, and sustainable energy is one of the most significant objectives of modern countries. Particularly, engineers who are in the position of operators of energy policies are supposed to have knowledge about energy, which is a comprehensive, complicated and abstract concept, in every sense. However, teaching energy meaningfully depends on interdisciplinary teaching. It is hard to transfer what you learn at school to real life with an education which gathers around a discipline and contains lots of theoretical knowledge.

\section{References}

Beaudreau, B. (2005). Engineering and economic growth. StructuralChange and Economic Dynamics, 16, 211-220. https://doi.org/10.1016/j.strueco.2004.05.001

Campbell, N. A., \& Reece, J. B. (2002). Biology (6th ed.). San Francisco: Pearson.

Chabalengula, V. M., Sanders, M., \& Mumba, F. (2011). Diagnosing students' understanding of energy and its related concepts in biological contexts. International Journal of Science and Mathematics Education, 10(2), 241-266. https://doi.org/10.1007/s10763-011-9291-2

Close, H. G., \& Scherr, R. E. (2015). Enacting conceptual metaphor through blending: learning activities embodying the substance metaphor for energy. International Journal of Science Education, 37(5-6), 839-866. https://doi.org/10.1080/09500693.2015.1025307

Creswell, J. W. (2013). Nitel araştırma yöntemleri; Beş yaklaşıma göre nitel araştırma ve araştırma deseni (Ed. \& Trans. Bütün M. \& Demir, S. B.) Ankara: Siyasal Kitabevi.

Diakidoy, I. A. N., Kendeou, P., \& Ioannides, C. (2003). Reading about energy: The effects of text structure in science learning and conceptual change. Contemporary Educational Psychology, 28, 335-356. https://doi.org/10.1016/S0361-476X(02)00039-5

Domenech, J. L., Gil-perez, D., Gras-marti, A., Guisasola, J., Torregrosa, J. M., Salinas, J., Trumper, R., Valdes, P., \& Vilches, A. (2007). Teaching of energy issues: A debate proposal for a global reorientation. Science \& Education, 16, 43-64. https://doi.org/10.1007/s11191-005-5036-3

Duit, R., \& Haeussler, P. (1994). Learning and teaching energy. In P. J. Fensham, R. F. Gunstone, \& R. T. White (Eds.), The content of science: A constructivist approach to its teaching and learning (pp.185-200). Bristol, PA: FalmerPress.

Eş, H., \& Sarıkaya, M. (2010). The investigation of teachers' opinion related to the acquisition of the unit, "electricity in our life", in primary education science and technology curriculum. E-Journal of New World Sciences Academy 
Education Sciences, 6(1), 32-45.

Güneş, H., \& Karaşah, Ş. (2016). The studies in science education from the past to the present and the importance of science education. Journal of Research in Education and Teaching, 5(3), 122-136.

Güneş, T., \& Taştan, A. F. (2016). Determination of perceptions of Science High School students on energy and their levels of interdisciplinary association. International Journal of Social Sciences and Education Research, 2(2), 625-635. https://doi.org/10.24289/ijsser.279072

Hecht, E. (2007). Energy and change. The Physics Teacher, 45, 88-92. https://doi.org/10.1119/1.2432084

Hırça, N., Çalık, M., \& Akdeniz, F. (2008). Investigating grade 8 students' conceptions of energy and related concepts. Journal of Turkish Science Education, 5(1), 75-85.

Kilıç, S., \& Cerit Berber, N. (2018). Researching students' perception of energy in terms of daily life through the concept mapping method by collecting photographs. National Education (Journal of Education and Social Sciences), 218, 91-112.

Lakoff, G., \& Johnson, M. (2005). Metaforlar: Hayat, Anlam ve Dil. (Ed. \& Trans. G. Y. Demir), Paradigma Yayınları, İstanbul.

Lancor, R. (2012). Using metaphor theory to examine conceptions of energy in biology, chemistry, and physics. Science and Education, 23(6), 1245-1267. https://doi.org/10.1007/s11191-012-9535-8

Lee, H., \& Liu, O. L. (2010). Assessing learning progressions of energy concepts across middle school grades: The knowledge integration perspective. Science Education, 94, 665-688. https://doi.org/10.1002/sce.20382

Mälkki, H., \& Paatero, J. V. (2014). Curriculum planning in energy engineering education. Journal of Cleaner Production, 106(11), 292-299. https://doi.org/10.1016/j.jclepro.2014.08.109

Marzano, R. J., Gaddy, B. B., \& Dean, C. (2000). What works in classroom instruction? ERIC Document, No: ED 468434.

Niebert, K., Marsch, S., \& Treagust, D. F. (2012). Understanding need sembodiment: a theory-guided reanalysis of the role of metaphors and analogies in understanding science. Science Education, 96, 849-877. https://doi.org/10.1002/sce.21026

Taber, K. S. (1989). Energy by many other names. School Science Review, 70(252), 57-62.

Tamimi, Y. (2005). An analysis of organization culture with metaphors (Unpublished master's thesis), Osmangazi Universty, Institute of Social Sciences, Eskişehir, Turkey.

Töman, U., \& Odabaşı, Ç. S. (2011). An investigation into the conceptions of energy at different educational levels. Bayburt University Journal of Bayburt Education Faculty, 6(1-2), 27-39.

Töman, U., \& Odabaşı, Ç. S. (2012). An investigation into the conception energy conversion at different educational levels. Erzincan University Journal of Education Faculty, 14(2), 289-312.

Ünal, Ç. G., Aktamış, H., \& Ergin, Ö. (2007). The views of 8th grade students about energy. Kastamonu Education Journal, 15(1), 175-184.

Yıldırım, A., \& Şimşek, H. (2011). Sosyal bilimlerde nitel araştırma yöntemleri. Ankara: Seçkin Yayıncılık.

Yürümezoğlu, K., Ayaz, S., \& Çökelez, A. (2009). Grade 7-9 students' perceptions of energy and related concepts. Necatibey Faculty of Education Electronic Journal of Science and Mathematics Education, 3(2), 52-73.

\section{Copyrights}

Copyright for this article is retained by the author(s), with first publication rights granted to the journal.

This is an open-access article distributed under the terms and conditions of the Creative Commons Attribution license which permits unrestricted use, distribution, and reproduction in any medium, provided the original work is properly cited. 